\title{
A COMPARATIVE STUDY BETWEEN CHINA AND MALAYSIA: INVESTIGATING THE INFLUENCE OF FIRST LANGUAGE (L1) SYNTAX IN SPEAKING ENGLISH (L2) AMONG PRIMARY SCHOOL STUDENTS
}

\section{Mahendran Maniam ${ }^{1+}$ \\ (D) Mardhiyah \\ Ridzuan $^{2}$ \\ Santhia A/P \\ Subramaniam $^{3}$ \\ Vigneshwary A/P \\ Sagathivan $^{4}$ \\ iD Yom Saridatul \\ Najwa Bt Abd Lahsan \\ Zhong Jingjing 6}

\author{
'English Language and Literature Department, Faculty of Languages and \\ Communication, Universiti Pendidikan Sultan Idris (UPSI), Malaysia. \\ 'Email:mahendran@fbk.upsi.edu.mv \\ ${ }_{2,3,5,5.6}$ Postgraduate Students, English Language and Literature Department \\ Faculty of Languages and Communication, Universiti Pendidikan Sultan \\ Idris (UPSI), Malaysia. \\ 'Email:mardhivahr@gmail.com Tel: +60143001162 \\ ${ }^{3}$ Email: santhia.subramaniam@gmail.com Tel: +601116967831 \\ "Email: vigneshwarysagathivan@gmail.com Tel: +60126479631 \\ ${ }^{5}$ Email:ym180282@gmail.com Tel: +60132083004. \\ ${ }^{6}$ Email: zhongjingjing_1998@_qq.com Tel:+8613531427864
}

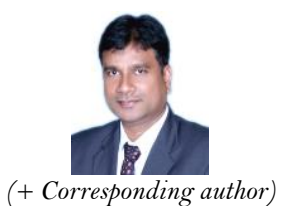

(+ Corresponding author)

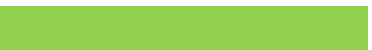

Article History

Received: 16 July 2021

Revised: 18 August 2021

Accepted: 22 September 2021

Published: 14 October 2021

\section{Keywords}

Second language acquisition Bahasa Melayu Negative transfer

Mother tongue

Language transfer

L1 influence.

\begin{abstract}
For Malaysian students, speaking in English is one of the most challenging skills to master, especially if they do not have a strong command of the language. Meanwhile in China, the English language is primarily employed as a means of academic communication and teaching. This paper aims to identify which linguistic items have been transferred positively and negatively from L1 (Bahasa Melayu and Mandarin) in speaking English (L2) among primary school students. A qualitative study among primary school students from China and Malaysia was carried out using purposive sampling. Based on the findings, four types of syntactic errors from the Malaysian students' speech were identified. It was evident that the students had difficulties to speak correctly in terms of sentence structure. The four syntactic errors found are simple past, simple present, verb 'to be' and subject-verb-agreement. Meanwhile, it has been found that Chinese students frequently produce linguistic mistakes during their utterances of L2 speech as a result of L1 interference. This research also exposed that the students are still unconsciously relying on their mother tongue to translate their sentence into L2. The study is expected to help ESL teachers to draw the analogies between corresponding L1 and L2 syntax constructions. The findings will contribute and direct the learners' attention to cross-language syntactic similarities and differences and thus guide them to a deeper understanding of underlying linguistic structure.
\end{abstract}

Contribution/ Originality: This study contributes to existing literature by suggesting better insights into mother tongue influence among ESL students in Malaysia and China. The literature of such comparative study is very limited (especially in terms of speaking skills) and the findings of this study will be of great help to ESL teachers in China and Malaysia. 


\section{INTRODUCTION}

After Bahasa Melayu, which is also a national language of Malaysia, English is one of the most significant language and widely used in Malaysia. For Malaysian students, speaking in English is one of the most challenging skills to master, especially if they do not have a strong command of the language. Then we investigate the Chinese Education. The English language is primarily employed as a means of academic communication and teaching for these Chinese students with class discussions, presentations, and assignments, to name a few, being conducted in English. However, it has been found that according to Dipolog-Ubanan (2016) Chinese students frequently produce linguistic mistakes during the creation of L2 speech as a result of L1 interference. L2 learners' native language structures have an impact on their ability to produce and improve spoken English (Hashim, 2017). This indicates that, while L2 learners' English language sentences may include acceptable grammar structures, suitable vocabulary items, and content, they may be structured wrongly and awkwardly. "Please can you assist me?" is an example of a request in which the second person pronoun is put first since that structure is typical in the L1. As a result, grammatical competence in the L2 learner does not always imply that they are effective in picking acceptable utterances that are relevant to real communicative circumstances. This is mentioned by Al-Ghamdi, Almansoob, and Alrefaee (2019) in their article " Pragmatic Failure in the Realization of the Speech act of Responding to Compliments among Yemeni EFL Undergraduates". According to Onwubiko (2012) the current issue of concern is how to increase English language competence in Malaysia to a level comparable to, if not higher than, that of the English medium days. As curriculum architects at the Education Ministry and instructors in schools have realised throughout the years, improving English language competency only through English courses in the school curriculum is insufficient. In national schools, many students use Bahasa Melayu as their primary language of instruction. Except for the English language course, all national school subjects are taught in Bahasa Melayu (Onwubiko, 2012). Malaysia is one such case. It is a multi-ethnic and multilingual country, with the Malay race accounting for 68.8 percent of the population in 2016. (Department of Statistics Malaysia). A historical examination of Malaysia's journey to independence and sovereignty reveals how important language was as a unifying factor. As stated in the Federation of Malaya 1956, "...Malay language as the official national language of the country while preserving and sustaining the growth of the language and culture of other communities living in the country," the government used Malay as the official language and medium of instruction in schools in order to unite all races. As a result, Malaysians have become skilled in one common language, Malay, throughout the years. In Malaysia, the national language is Bahasa Melayu and it is also the widely spoken language among its people. Because of its worldwide importance, English is taught as a second language (L2), with most pupils learning the language through classroom instruction in schools. The use of L1 in English language instruction has become a foregone conclusion. With Malaysian history and classroom setting in mind, utilising L1 in English classrooms may be a useful learning technique. However, excessive usage of $\mathrm{L} 1$ can be a stumbling block for learners since it reduces the chance to practise speaking in L2. This will obstruct the learners' ability to learn the language. Learners in 'English as a Second Language' (ESL) and 'English as a Foreign Language (EFL)' classes are similarly susceptible to negative influence in this way.

Previous research has demonstrated the benefits and drawbacks of utilising L1 in English classes, as well as students' attitudes about the usage of L1. Thus, this study seeks to identify which linguistic items have been transferred positively from L1 (Bahasa Melayu and Mandarin) in speaking English (L2) among primary school students and also identify which linguistic items have been transferred negatively from L1 (Bahasa Melayu and Mandarin) in speaking English (L2) among primary school students.

\section{BACKGROUND OF THE STUDY}

Since the advent of the German-Translation Method (GTM), concerns surrounding the consequences of utilising the first or native language (L1) in second language (L2) classrooms have been hotly debated among 
language academics (Sa'd \& Qadermazi, 2015). (GTM), Due to differing and conflicting viewpoints on the subject, no major or final findings or agreements have been reached. The use of L1 as the primary medium of instruction and communication is influenced by a number of factors, which has an impact on the acquisition of other secondary languages. In English, Bahasa Melayu inferences are one of the most common sources of syntactic mistakes among Malaysian learners. According to Gedion, Tati, and Peter (2018), pupils immediately converted Malay terms into English words, resulting in sentence distortion. First language (L1) or mother tongue has negative effects on writing English language (L2), which has a significant impact on secondary school pupils' development of English language abilities (Muriungi \& Mbui, 2013).

According to Noor, Embong, and Aigbogun (2015) students at the tertiary level of study have difficulty interacting and socialising in the English language. In a research conducted in Hong Kong by Gan (2012), local students regarded interacting in English as uncomfortable, despite their awareness of the necessity of practising the language. Students prefer to interact with one another in their first language, while others see language as an integral component of their identity and culture. This is in line with Al Sharaeai (2012) assertion that "keeping on to the first language is like hanging on to your own culture."

\section{STATEMENT OF PROBLEM}

It is often claimed that, when students transfer grammar knowledge from L1 into L2, errors may occur due to the structural grammar differences between the source and the target language. One factor is a population's demographics. Because each race or ethnicity has its own distinct language, the predominance of one race over the others naturally promotes the usage of the related language over the others as the other races assimilate to the main language. Apart from their inability to write and speak correctly in English, pupils have English language phobia too, as said by Noor et al. (2015). This dread has spread to other topics taught in the language. They also stated that owing to a lack of interest in English language education, parents and guardians do not highlight the significance of the English language to their children.

In China, L1 interference in L2 speech is frequent, producing communication difficulties for English language learners. One issue is that classroom English language instruction concentrates on memorization of grammatical rules and vocabulary, textbook exercises, and reading abilities (Ye, 2013). Although there is a greater emphasis on learning English language forms and functions, there is a lack of practise in real-life situations when the memorised language norms may not appear in spontaneous communicative speech. As a result, the students may appear to have mastered the English language by receiving high results on their English language tests, but they are unable to communicate effectively in English (Dipolog-Ubanan, 2016). Furthermore, many Chinese students do not have the opportunity to explore English-speaking environments in China, resulting in limited exposure and practise. As a result, after graduating from high school and continuing their education, they transfer their cognitive processes and linguistic rules from their native Chinese language to English during communication (Zou, 2013). As a result, erroneous grammatical constructions emerge. Because the discourse is mostly translated from their original tongue, it has an odd vocabulary and even loses its intended meaning. For example, when the Chinese send-off visitors, they say “,” (zai jian, man zhou), but when translated into English, they may say "Goodbye, gently walk.” As a result, even pupils with excellent language skills may make mistakes in real-life circumstances while speaking with foreigners (Ji, 2008).

\section{RESEARCH OBJECTIVES}

This paper aims to identify which linguistic items have been transferred positively from L1 (Bahasa Melayu and Mandarin) in speaking English (L2) among primary school students and also identify which linguistic items have been transferred negatively from L1 (Bahasa Melayu and Mandarin) in speaking English (L2) among primary school students. The following research questions were also addressed in this paper: 


\section{RESEARCH QUESTIONS}

1. Which linguistic items have been transferred positively from L1 in speaking English (L2) for a short speech among primary school students?

2. Which linguistic items have been transferred negatively from L1 in speaking English (L2) among primary school students?

\section{LITERATURE REVIEW}

Second Language Acquisition (SLA) mainly seeks to investigate the acquisition of a new language beyond the mother tongue or L1 (Aljumah, 2020). It is a systematic study of how people learn a language other than their mother tongue. According to Singh and Maniam (2020) Second Language Acquisition (SLA) is the study of how students acquire a second language (L2) additionally to their first language (L1). Thus, any other language apart from the first language is called a second language (SL) or also referred to as a target language (TL). The SLA process involves errors, which are said to be caused by factors in the learner's first language (interlinguistic factors) and the target language (TL) themselves (Syed, 2020). As stated by Denizer (2017) the term first language (L1), refers to mother tongue which is not only the language one learns from one's mother but also the speaker's dominant and home language. It's also called native language. In line with that, according to Romero and Manjarres (2017) the first language (L1) becomes the first source for a learner to understand how a language works, specially to young learners who are in the concrete operation phase, as they tend to monitor how they acquire and learn second language or foreign languages. The experience or knowledge, which a person has about his mother tongue (L1), would definitely be going to interfere in the second language (L2). This is happening because any individual who starts mastering another information or abilities tends to utilize their unique psychological design, including the L1 information and conceptual reasoning capacity learned through the L1, which establish the first intellectual construction of SLA; this is the establishment of data preparation. Denizer (2017) pointed out that the biggest effect of mother tongue (L1) interference can be seen in the speaking as a language skill. The findings of the study show that learners making errors especially in speaking without preparation and translating a passage into the target language (L2). Moreover, it is possible to say that learners especially have difficulty with determiners, sounds, sentence structures, and articles.

According to Syed (2020) first language interference is the overwhelming reason for erroneous or deviant L2 linguistic forms. The similarities or the differences between the two language systems determine the intensity of influence. When the two languages are similar, positive transfer occurs whereas differences result in inhibition or negative transfer manifesting itself in erroneous or deviant L2 forms. Hence, a correct understanding of the role of L1 in the acquisition of L2 is of great significance to identify the syntax which has been transferred negatively and positively from L1 to L2.

Numerous studies have been carried out on the influence of first language to the second language, and it has been one of the controversial issues in second language acquisition for decades. Data from several studies have identified the influence of the first language (L1) to have a negative effect in the second language (L2). According to Masood, Shafi, Rahim, and Darwesh (2020) students face interference from their native language when speaking English and it cause the negative transfer from the L1 to L2 structure. Moreover, Krish and Oh (2020) also stated that first language interference lead to grammatical and structural errors in the English (L2) language. They also add the language interference resulted in misunderstanding and frustration for both speaker and hearer because the direct translations and grammatical errors may convey the messages that contrast from what the students initially intend to say.

According to Rahmah, Dalimunthe, Tien, Sholihatul, and Maryati (2020) L1 has a significant influence on the learning of L2. The findings of the study particularly emphasize some difficulties that Chinese speaking learners may face to learn English, which include phonological, morphological, and syntactic interferences. The study also 
reveals two points of L1 syntactic interference on English which are the use of definite and indefinite articles and the reduplication makes when wants to highlight the meaning of particular words. Similarly, Syed (2020) also pointed out first language interference presents syntax error in English language. Furthermore, Singh and Maniam (2020) revealed that participants use their knowledge of L1 in writing of L2 and there was no positive translation found in the essay writing practices whereas the researchers only found errors of negative translations.

As stated by Syed (2020) L1 influence is said to be negative in most cases because no two languages share the same linguistic properties; if they do, the acquisition of the L2 is facilitated by the L1. Meanwhile, the study conducted by Siu and Ho (2020) showed the first longitudinal evidence of a transfer of syntactic awareness in bilingual children acquiring typologically different languages. They detailed that in L2 instruction, if the teachers draw analogies between corresponding L1 and L2 syntactic constructions, this explicit instruction directs children's attention to cross-language syntactic similarities and differences, and thus helps them cultivate a deeper understanding of underlying linguistic structure. Thus, children can then make appropriate modification to L1 resources to make them serviceable in L2 learning performance. Farha and Azlina (2020) expressed that first language (L1) aids the writing process and act as a tool in L2 classroom because it gives the students the opportunity to take part in the class and there will be two-way communication between the students and teacher.

Researchers use the theory of comparative analysis to conduct this research. According to Nargiza (2020) the theory of comparative analysis continues to be an influential structure in the field of second language acquisition; language comparison is used to explain difficult areas to students. Following this theory can help to have a better understand the process of acquiring a second language structure and to improve L2 learning and teaching. In addition, as mention by Nargiza (2020) adopting comparative theory is a good indicator to its effectiveness in describing L2 learners' errors especially those which can be due to interference from the first language (L1) or mother tongue.

Other than that, Friedrichsen (2020) cited Stephen Krashen has influenced the world of SLA and his five hypotheses namely Acquisition Learning hypothesis, monitor hypothesis, Natural Order hypothesis, Input hypothesis, and Affective Filter hypothesis play a significant role in second language acquisition. The theory helps to differentiate between language acquisition and language learning (the acquisition-learning distinction), claiming that acquisition is implicit and subconsciously acquired in informal situations while learning is explicitly and consciously done in formal situations.

\section{METHODOLOGY}

\subsection{Research Design}

This study uses the qualitative method to carry out the research. The paper aims to identify which linguistic items have been transferred positively from L1 (Bahasa Melayu and Mandarin) in speaking English (L2) among primary school students and identify which linguistic items have been transferred negatively from L1 (Bahasa Melayu and Mandarin) in speaking English (L2) among primary school students. A qualitative study among primary school students from China and Malaysia.

\subsection{Sampling}

In this study, the sampling method is purposive sampling. A purposive sample referred to as a judgmental or expert sample, is a type of nonprobability sample. According to Merriam (1998) using purposive sampling allows researchers to understand a phenomenon in depth. The main objective of a purposive sample is to produce a sample that can be logically assumed to be representative of the population (Lavrakas, 2008).

Figure 1 shows the research design of the study. Using purposive sampling, ten participants from each China and Malaysia were asked to give a short speech. Then eight of the twenty students, four from each country, were selected for in-depth interviews. The respondents were between 7 and 12 years old. And they had learned English 
as a second language during their primary school era in a formal setting. The sample from the two countries were adequate to provide a clear picture of the research objectives.

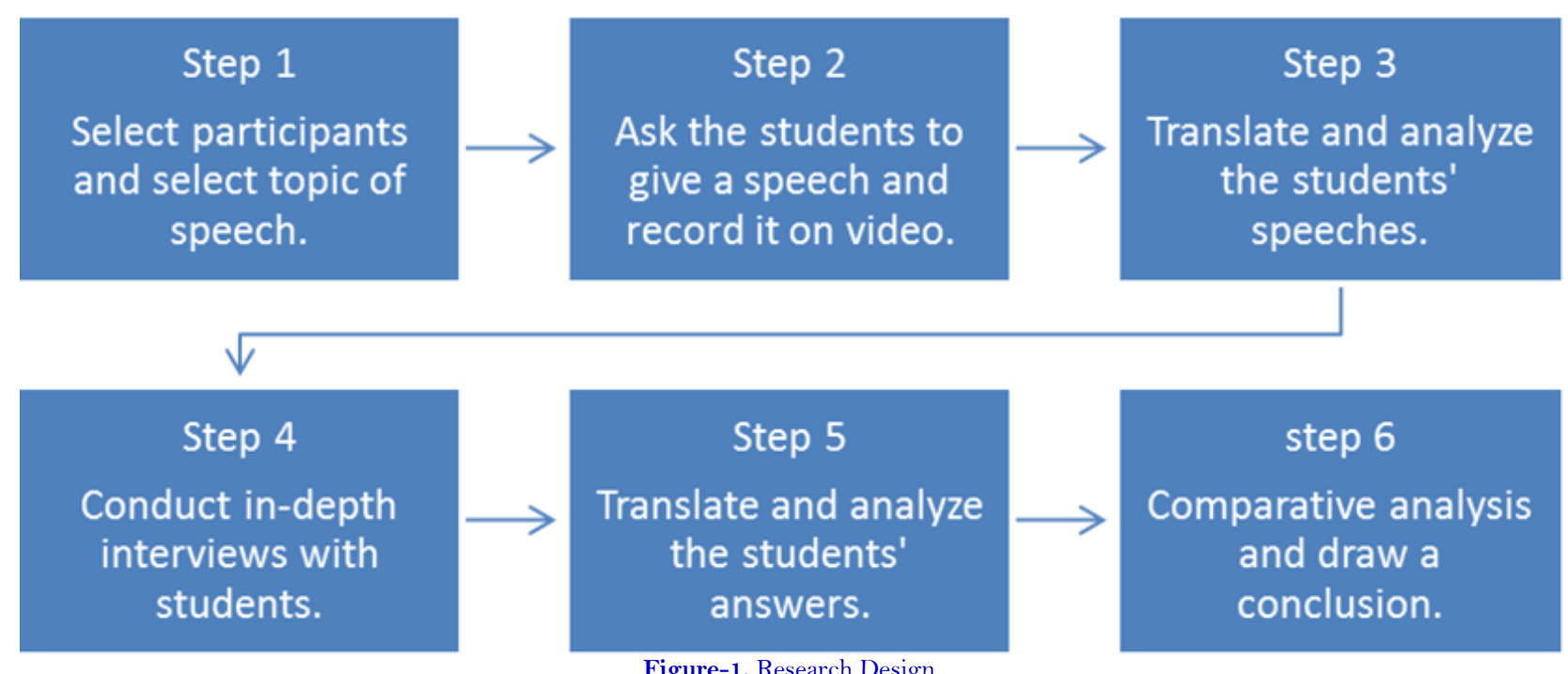

\subsection{Instrument}

This study used student's speech and in-depth structured interviews as the instrument to collect the data.

Firstly, students from China and Malaysia gave a speech about 100 words, based on the topic given by the researcher, that is, "The Day I Will Never Forget". And then they were asked to send the recorded audio of their speech to the researcher. The researchers translated and analyzed their speeches.

Secondly, the researchers interviewed students from two different countries. Interviews are adequate to investigate the topic or phenomena not directly observable. Moreover, Interviews are interactive thus the researcher can obtain more information to conclude. During the interview session, both the researcher and interviewees can make clarifications about the reason syntax transferred negatively and positively from L1 to L2. The interview consisted of several questions prepared in advance to remain focused on the research. Students from each country answered questions posed by the researchers. Each interview lasted for about 10 minutes. The researcher transcribed the interview into text data. The responses from the interview would support the findings gathered from the recorded speech.

Table-1. The Interview Questions.

\begin{tabular}{l|l}
\hline Question 1: & $\begin{array}{l}\text { Do you think in Mandarin/ Bahasa Melayu before you speak in English? } \\
\text { If yes, does it help you to speak English better? }\end{array}$ \\
\hline Question2: & $\begin{array}{l}\text { Do you think in English before you speak it? } \\
\text { If yes, does it help you to speak English better? }\end{array}$ \\
\hline Question3: & $\begin{array}{l}\text { Which is easier for you to speak in English, thinking in Mandarin/ } \\
\text { Bahasa Melayu or in English? }\end{array}$ \\
\hline
\end{tabular}

\section{FINDINGS AND DISCUSSION}

\subsection{Findings \\ 8.1.1. Short Speech}

The purpose of this research is to identify the negative and positive transfer of syntax from L1 to L2 in speaking skills. The voice-notes/videos were transcribed and analysed for any errors in translation. Based on the data gathered from Malaysian participants in Table 1, there were evidences of negative translations from the errors made which means, the transfer of syntax rules from L1 has negative effects on students' speaking skills. Some of 
the errors can be found in subject-verb-agreement, the use of articles, 'to be' verb, as well as tenses (simple present tense simple past tense). Some of the extracts of the voice transcriptions from the students' speech are as follows:

8.1.2. The Day I Will Never Forget

1) Subject-Verb-Agreement

\section{Student 3}

"She like to cook fried chicken for me."

The correct phrase in English should be: "She likes to cook fried chicken for me."

Bahasa Melayu (L1): Dia suka masak ayam goreng untuk saya.

\section{Student 4}

"My father bought me a lot of toy."

The correct phrase in English should be: "My father bought me a lot of toys."

Bahasa Melayu (L1): Ayah saya membelikan saya banyak mainan.

\section{Student 7}

"Because the doctor, it hurt here."

The correct phrase in English should be: "Because of the doctor, it hurts here."

Bahasa Melayu (L1): Disebabkan oleh doctor, ianya sakit di sini.

2) Simple Past Tense

\section{Student 5}

"My mother cook a lot of dishes such as ketupat rendang, ayam and so much more."

The correct sentence in English should be: "My mother cooked a lot of dishes such as ketupat rendang, chicken and so much more." (simple past tense)

Bahasa Melayu (L1): Ibu saya telah memasak pelbagai hidangan seperti ketupat rendang, ayam dan banyak lagi.

\section{Student 8}

"I go with my family. I go to the beach. I go swimming."

The correct sentence in English should be: "I went with my family. I went to the beach. I went swimming."

Bahasa Melayu (L1): Saya pergi bersama keluarga saya. Saya pergi ke pantai. Saya pergi berenang.

3) Simple Present Tense

\section{Student 3}

"She like to cook fried chicken for me."

The correct sentence in English should be: "She likes to cook fried chicken for me."

Bahasa Melayu (L1): Dia suka masak ayam goreng untuk saya.

4) Verb 'to Be'

\section{Student 6}

"I just playing football as it's just a toys."

The correct sentence in English should be: "I was just playing with a ball since it was just a toy."

Bahasa Melayu (L1): Saya cuma bermain dengan sebiji bola memandangkan ia adalah sejenis permainan.

\section{Student 4}

"My name Siti Nur Madinah Batrisya". 
The correct sentence in English should be: "My name is Siti Nur Madinah Batrisya".

Bahasa Melayu (L1): Nama saya adalah Siti Nur Madinah Batrisya.

Below are some of the syntactical errors that can be found from the participants from China. The errors made were different compared to the ones made by the Malaysian participants and are highlighted below.

\section{Singular and Plural.}

There is no separate plural structure in Mandarin. It means that the form of an object will not change whether it is one or more.

"My hobby are play basketball and listening to music".

Correct sentence: "My hobbies are playing basketball and listening to music".

2. Tenses.

In the sentence structure of Mandarin, there is no separate distinction between tenses. No matter whether it is the past tense, the present tense or the future tense, verbs do not change tenses. In Mandarin, the time of the incident can be determined directly.

"My mother buys me gifts for my birthday". (Translated from Mandarin)

"My mother bought me gifts for my birthday". (English)

\section{Gender Distinction}

In Mandarin, he and she are pronounced the same "ta", so it is often easy for Chinese students to confuse he with she in the spoken language.

"My father is a cook. She goes to work by bus". (Translated from Mandarin)

"My father is a cook. He goes to work by bus". (English)

4. Chinese Pinyin and English Alphabet are very similar, English beginners often confuse Alphabet and Pinyin, resulting in the wrong pronunciation. Apart from the letter V, the rest of the 25 English letters appear in Chinese Pinyin, but the pronunciation is different.

5. In English sentence structure, time is often placed at the beginning or the end of the sentence, while in Mandarin, time often follows the subject.

"I sometimes listen to music". (Mandarin)

"Sometimes I listen to music". (English)

\subsection{Responses from the Interview Session}

The interview was carried out with the help of the respondents' guardians or parents. Researchers gave instructions and the list of questions to ask. Out of eight interviewees, four of them were taken from China and the remaining four from Malaysia. The researcher received the audio recording from the parents/guardians and transcribed them. Some of the parents/guardians had to rephrase the questions for the participants to understand and answer them. All of the interviewees gave short answers to the questions.

The first question asked was, whether they think in their own language (L1) before they speak in English. The data demonstrates that two students $(2 / 4,50 \%)$ responded 'yes' because it helps them in speaking English. In contrast, the students who responded 'no' would not be comfortable thinking in Bahasa Melayu before speaking in English. The parents/guardians did not ask for situations where they would have to think in their first language before speaking in English. The other two interviewees (2/4, 50\%) responded 'no', because they sounded like they have been raised speaking in English a lot more compared to their first language. This applied to the second question as well. The students who think in Bahasa Melayu before speaking in English did not think in English before they speak and vice versa. The last question was to find out which of the two languages (English or Bahasa 
Melayu) makes it easier for them so speak in English. On the other hand, all students $(4 / 4,75 \%)$ from China responded 'yes' to thinking in Mandarin before speaking in English and three of them said that it helps them to speak English better. Only two of the participants $(2 / 4,50 \%)$ stated that they think in English before they speak it and that it helps them to speak the language better. Overall, three of the participants $(3 / 4,75 \%)$ responded that thinking in their mother tongue language makes it easier for them to speak in English.

The findings have shown that it is clear that the students involved in this study use their knowledge of first language (L1) in speaking English language (L2). Students usually resort to using L1 to figure out words and how to construct sentences in order for them to speak L2. Kern (1994) mentioned, based on Krashen's Affective Filter Theory of acquisition and learning, learner will have greater confidence to use the language by making the input more familiar. Thus, majority of the students think that using L1 definitely helps them in speaking using English language. The findings have also proven that students have difficulties distinguishing the right syntax to use when speaking in English. This is in line with Javed and Phil (2012) that it is crucial for language teachers to make sure their students are proficient in the structure of both first language and second language. Singh and Maniam (2020) stated that the translation method from L1 to L2 is an unconscious process. Thus, having a strong foundation for both languages would help the students to be proficient in both languages at the same time.

\section{CONCLUSION}

The research identified four types of syntactic errors from the Malaysian students' speech. It was evident that the students had difficulties to speak correctly in terms of sentence structure. The four syntactic errors found were simple past, simple present, verb 'to be' and subject-verb-agreement. This research also exposed that the students were still unconsciously relying on their mother tongue to translate their sentence into L2. These L1 translations led to misunderstanding for the researchers and students because of the direct translation and grammatical errors may impart messages that vary from what the students intended to say. Moreover, the researchers identified that the students had very limited vocabulary. They had difficulties in choosing the appropriate words when speaking. In addition, the different grammatical form of a word such as inflections was the reason for students' difficulties in learning vocabulary. However, most of the students had a negative influence of L1 in terms of syntax for L2 speaking skills. There were only a few of them mixed with L1 words. Furthermore, the students needed some help from their parents or guardians to prompt them.

On the other hand, the participants from China made different kinds of errors. For example, in terms of singular and plural nouns. There is no separate plural structure in Mandarin. It means that the form of an object will not change whether it is one or more. Next is, sentence tenses. There is no separate distinction between tenses in Mandarin sentence structure. No matter whether it is the past tense, the present tense or future tense and verbs do not change tenses. The time of the incident can be determined directly in Mandarin. Furthermore, 'he' and 'she' are pronounced the same 'ta', so it is often easy for Chinese participants to confuse between he and she in the spoken language. As Chinese Pinyin and English Alphabet are very similar, English beginners often confuse the Alphabet and Pinyin, resulting in the wrong pronunciation. Apart from the letter V, the rest of the 25 English letters appear in Chinese Pinyin, but the pronunciation is different. Lastly, in English sentence structure, time is often placed at the beginning or the end of the sentence, while in Mandarin, time often follows the subject. By and large, students from both the countries displayed the interference of mother tongue (negative transfer) in their spoken language.

\section{LIMITATION}

The first limitation of this study is lack of prior research studies on the topic. There are only a few researches done on how L1 affects L2 speaking skills in terms of syntax. 
The second limitation of this study is the researchers could not reach the participants directly or face-to-face because of the COVID 19 pandemic. Thus, the instructions on how to conduct the short speech were given to the parents and guardians. The researchers have explained the instructions in detail with the parents and guardians.

\section{RECOMMENDATION}

Based on the conclusion made, the researchers strongly recommend that the participants should develop reading habits and practice using new words in their daily conversation. Besides, this can be done by having regular conversation with parents, guardians and teachers. Moreover, the participants should take note of the mistakes and correct them. Apart from this, the participants should try to get into the habit of thinking in English rather than in their mother tongue. At the same time, the teachers can use strategies like discussing meaning with the help o illustrations. The participants should take the opportunity to improve their L2 speaking skills although they might still switch to their L1 occasionally.

Funding: This study received no specific financial support.

Competing Interests: The authors declare that they have no competing interests.

Acknowledgement: All authors contributed equally to the conception and design of the study.

\section{REFERENCES}

Al-Ghamdi, N. A., Almansoob, N. T., \& Alrefaee, Y. (2019). Pragmatic failure in the realization of the speech act of responding to compliments among Yemeni EFL undergraduates. 3L: The Southeast Asian Journal of English Language Studies, 25(4), 227-240. Available at: https://doi.org/10.17576/31-2019-2504-14.

Al Sharaeai, W. A. A. (2012). Students' perspectives on the use of L1 in English classrooms. Graduate Theses and Dissertations. 12898.

Aljumah, F. H. (2020). Second language acquisition: A framework and historical background on its research. English Language Teaching, 13(8), 200-207. Available at: https://doi.org/10.5539/elt.v 13n8p200.

Denizer, E. N. (2017). Does mother tongue interfere in second language learning? Journal of Foreign Language Education and Technology, 2(1), 39-54.

Dipolog-Ubanan, G. (2016). L1 influence on writing in L2 among UCSI Chinese students: A case study. Pertanika Journal of Social Science and Humanities, 24, 1841-1853.

Farha, B., \& Azlina, A. A. (2020). L1 (Bahasa Malaysia) impact in process and product of learning writing in 12 (English). International Journal of Applied Science and Engineering Review, 1(2), 28-55.

Friedrichsen, A. (2020). Second language acquisition theories and what it means for teacher instruction. Retrieved from: https://nwcommons.nwciowa.edu/education_masters/200/.

Gan, Z. (2012). Understanding L2 speaking problems: Implications for ESL curriculum development in a teacher training institution in Hong Kong. Australian Journal of Teacher Education, 37(1), 43-59. Available at: http://dx.doi.org/10.14221/ajte.2012v37n1.4.

Gedion, Tati, \& Peter. (2018). A syntactic errors analysis in the Malaysian ESL learners. Journal of Applied Linguistics and Language Research, 8(3), 98-104.

Hashim, A. (2017). Crosslinguistic influence in the written English of Malay undergraduates. Journal of Modern Languages, 12(1), 60-76.

Javed, M., \& Phil, M. (2012). Strength for today and bright hope for tomorrow etymological analysis of the English language words. Language in India, 9(12), 580-592.

Ji, P. (2008). Pragmatics and pedagogy in college English teaching. Shanghai: Shanghai Foreign Language Education Press.

Kern, R. G. (1994). The role of mental translation in second language reading. Studies in Second Language Acquisition, 16(4), 441461. Available at: https://doi.org/10.1017/s0272263100013450.

Krish, P., \& Oh, C. M. (2020). A case study of L1 interference in speech acts among Chinese L2 students 3L. The Southeast Asian Journal of English Language Studies, 26(1), 106 - 118. Available at: https://doi.org/10.17576/31-2020-2601-08. 
Lavrakas, P. J. (2008). Encyclopedia of survey research methods: SAGE Publications, Inc.

Masood, M. H., Shafi, S., Rahim, M. Y., \& Darwesh, M. A. (2020). Interference of L1 (Urdu) in L2 (English) in Pakistan: Teaching English as a second language. International Journal of Applied Linguistics and English Literature, 9(5), 110-118. Available at: https://doi.org/10.7575/aiac.ijalel.v.9n.5p.110.

Merriam, S. B. (1998). Qualitative research and case study applications in education. San Francisco: Jossey-Bass.

Muriungi, P. K., \& Mbui, M. K. (2013). The influence of mother-tongue maintenance on acquisition of English language skills among day secondary school students in Imenti South district, Kenya. International Journal of Linguistics, 5(1), 296. Available at: https://doi.org/10.5296/ijl.v5i1.3318.

Nargiza, N. (2020). The contrastive analysis hypothesis: A case study of an Uighur-Uzbek-Russian multilingual woman. 354355.

Noor, A. M., Embong, A. M., \& Aigbogun, O. (2015). Using L1 in L2 classrooms: A case study among secondary school students of mixed English language proficiencies. International Journal of Arts \& Sciences, 8(2), 75-86.

Onwubiko, E. C. (2012). Unifying role of Malay language in a multilingual nation: A case of Malaysia. US-China Foreign Language, 10(7), 1349-1354.

Rahmah, F., Dalimunthe, M., Tien, R., Sholihatul, H. D., \& Maryati, S. (2020). L1 interference on L2 acquisition: A case study of a Chinese learner in the U.S. 584-587. Paper presented at the Proceedings of the 7th International Conference on Multidisciplinary Research - ICMR, Sumatera Utara, Indonesia.

Romero, Y., \& Manjarres, M. P. (2017). How does the first language have an influence on language learning? A case study in an English ESL classroom. English Language Teaching, 10(7), 123-139. Available at: https://doi.org/10.5539/elt.v10n7p123.

Sa'd, S. H. T., \& Qadermazi, Z. (2015). L1 use in EFL classes with English-only policy: Insights from triangulated data. Center for Educational Policy Studies Journal, 5(2), 159-175.

Singh, A. K. G., \& Maniam, M. (2020). A case study on the influence of first language syntax (L1) in writing English (L2) essays among form two secondary students. Universal Journal of Educational Research, 8(7), 2914-2920. Available at: https://doi.org/10.13189/ujer.2020.080719.

Siu, T.-S. C., \& Ho, S.-H. C. (2020). A longitudinal investigation of syntactic awareness and reading comprehension in ChineseEnglish bilingual children. Learning and Instruction, 67, 101327. Available at: https://doi.org/10.1016/j.learninstruc.2020.101327.

Syed, M. I. (2020). L1 interference in the acquisition of English syntax and lexis. 3L: The Southeast Asian Journal of English Language Studies, 26(1), 135-155. Available at: http://doi.org/10.17576/3L-2020-2601-10.

Ye, W. (2013). Achieving coherence in persuasive discourse: A study of Chinese ESL undergraduates in the United States. ProQuest Dissertations Publishing, 3592011.

Zou, R. (2013). The common English errors committed by Chinese national students in ELC, UCSI. Unpublished Project Paper for Bachelor of Arts in English Language and Communication. UCSI University: KL, Malaysia.

Views and opinions expressed in this article are the views and opinions of the author(s), International Journal of Asian Social Science shall not be responsible or answerable for any loss, damage or liability etc. caused in relation to/arising out of the use of the content. 